ELORE (ISSN 1456-3010), vol. 15 - 2/2008.

Julkaisija: Suomen Kansantietouden Tutkijain Seura ry.

[http://www.elore.fi/arkisto/2_08/sal2_08.pdf]

\title{
KIRJA-ARVIO:
}

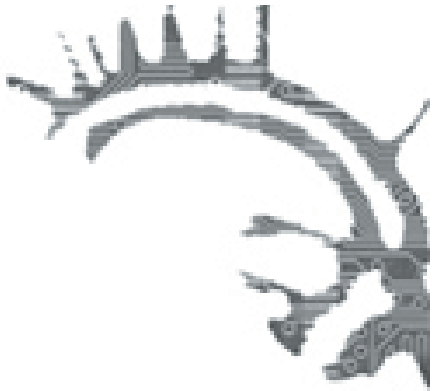

\section{TYTTÖKULTTUURIN PITKÄT KAARET}

Henriksson, Blanka 2007: "Var trogen i allt". Den goda kvinnan som konstruktion i svenska och finlandssvenska minnesböcker 1800-1980. Åbo: Åbo Akademis förlag. 292 sivua.

\section{Kirsti Salmi-Niklander}

Sain ensimmäisen muistokirjani neljä-viisivuotiaana 1960-luvun alun Joensuussa. Siihen kirjoittivat ja liimasivat kiiltokuvia perheenjäsenet ja kotiapulaiset, joista eräs kirjoitti suositun hengellisen laulun alkusäkeistön (sanat Emanuel Tamminen, sävel Mikael Nyberg):

Kun nuoruuden aika on ruusuinen, ja riemuinen sen joka puoli, ota tiestäsi vaari ja suunnasta sen, älä kaikista ruusuista huoli.

Muistan, miten tämä muistosäe askarrutti minua. Miksi jotain tiettyjä ruusuja ei pitäisi huolia, yleensähän kuului asiaan olla kaikesta saamastaan kiitollinen? Ja mitä vaarilla oli tekemistä tämän kanssa?

Nämä muistikuvat palasivat mieleeni lukiessani Blanka Henrikssonin folkloristiikan väitöskirjaa, joka käsittelee ruotsalaista ja suomenruotsalaista muistokirjakulttuuria 1800- ja 1900-luvulla. Tutkimuksen historiallinen kaari on pitkä, ja tekijä on nähnyt paljon vaivaa laajojen aineistojen kokoamisessa ja analysoimisessa. Kaikkiaan aineistona on 265 muistokirjaa vuosilta 1800-1980. Tutkimusprosessin osatuotoksena on syntynyt tietokanta Minnesbok. Runoaineiston kontekstualisoimisessa tekijä on hyödyntänyt lapsille ja nuorille suunnattuja painettuja julkaisuja sekä kasvatushistoriallista kirjallisuutta.

Muistokirjatraditio on hyvä esimerkki vajonneesta kulttuurituotteesta. Tradition edeltäjiä ovat ne muistokirjat (ruots. stamböcker), joihin 1500-1700-luvun nuoret aatelismiehet ja opiskelijat keräsivät mietelmiä ja muistokirjoituksia tapaamiltaan merkittäviltä henkilöiltä ja uusilta ystäviltä. Myöhemmin 1800-luvulla muistokirjoista 


\section{TYTTÖKULTTUURIN PITKÄT KAARET}

(ruots. minnesböcker) tuli naisten perinnettä ja vihdoin 1900-luvulla lastenkulttuuria. Samalla muistokirjojen sisältö triviaalistui ja yksinkertaistui runoiksi ja lopulta nonsense-loruiksi.

Muistokirjojen kuten yleensäkin kirjoitetun perinteen tutkimus on ollut folkloristiikan marginaalialuetta. Sillä on kuitenkin monissa maissa omat tutkijansa ja asiantuntijansa, kuten Ruotsissa Bengt af Klintberg ja Norjassa Gry Heggli. Blanka Henriksson on löytänyt myös vähemmän tunnettuja kansainvälisiä tutkimuksia, joista erityisesti Olga Vainstheinin tutkimus venäläisestä muistokirjaperinteestä antaa kiinnostavia vertailunäkökulmia. Vertailu suomenkielisen tutkimuksen kanssa jää ilmeisesti kielivaikeuksien takia varsin ohueksi, vaikka Henriksson viittaa muun muassa Leea Virtasen ja Kirsti Penttisen tutkimuksiin.

Blanka Henriksson etsii muistokirjoista hyvän naisen mallia ja sen konstruoimisen keinoja: mitä ominaisuuksia on hyvällä naisella ja mitä hänen tulee tavoitella? Tämän keskeisen kysymyksen avulla hän on onnistunut saamaan hyvin laajan aineistonsa hallintaan. Tutkimusmetodina Henriksson käyttää lähilukua, jonka hän määrittelee yhdistelmäksi kulttuurianalyysin tematisointia (kategorioiden ja arvostusten määrittelyä), grounded theorya ja kerronnan tutkimusta. Laajasta aineistosta hän on etsinyt teemoja ja niiden yhdistelmiä avainsanojen avulla. Tutkimuksen tulokset on jäsennelty ja esitetty selkeästi, lukijaystävällisesti ja havainnollisesti. Åbo Akademin julkaisusarja on kiitettävästi panostanut kuvitukseen.

\section{KIRJOITTAMISEN KEINOT JA TRADITIOT}

Tutkimuksen ehkä yllättävimpiä tuloksia on sukupolvien välisen tradition välittymisen suuri merkitys muistokirjaperinteessä. Oman muistokirjan saaminen on merkki siitä, että pikkutyttö on tullut luku- ja kirjoitustaitoiseen ikään. Hyvin usein äiti on antanut tyttärelle ensimmäisen muistokirjan ja myös opastaa tradition omaksumiseen. Tämä piirre korostuu 1900-luvun loppupuolen muistokirjoissa, joista tulee yhä selvemmin lastenkulttuuria.

Henriksson erittelee oivaltavasti kirjoittamisen keinoja kuten koodi- ja salakieliä, visuaalista leikittelyä ja metarunoutta, jossa pohditaan muistovärssyn kirjoittamisen ongelmallisuutta. Kirjahistoria ja kirjoittamisen historia voisivat syventää muistokirjaperinteen taustoja, vaikka muistokirjat kuuluvat myös näiden uusien tieteenalojen piirissä marginaaliin. Muistokirjoille löytyy kuitenkin vertailukohteita modernin ajan käsikirjoituskulttuurin piiristä. Commonplace book, johon talletettiin sitaatteja ja mietelmiä oli 1600-1700-luvuilla suosittu, muistokirjaa muistuttava käsikirjoituskulttuurin muoto. Amerikkalainen Ellen Gruber Garvey (2007) on tutkinut 1800-luvun leikekirjoja (engl. scrapbooks), joista vastaavasti on vähitellen tullut lasten ja nuorten ajanvietettä.

Käsinkirjoitetut lehdet, joita olen itse tutkinut, kokivat 1800-luvulla vastaavanlaisen marginaalistumisprosessin kuin muistokirjat. Suomessa (ja ilmeisesti myös muissa Pohjoismaissa) ne kuitenkin elvytettiin nuorten aikuisten vakavan ideologisen keskustelun välineeksi 1800-luvulla ja 1900-luvun alussa. Ne levisivät myös kansan- 


\section{KirSti Salmi-NiKLander}

liikkeiden mukana eri yhteiskuntaluokkien pariin ja maaseudulle. Toisin kuin käsinkirjoitetut lehdet, muistokirjat pysyttelevät omassa runollisessa, hitaasti muuttuvassa maailmassaan. Blanka Henriksson on löytänyt vain muutamia sotien tapahtumiin liittyviä kommentteja suomenruotsalaisista muistokirjoista.

Muistokirjojen sukua ovat myös 1900-luvun alun nuorten tyttöjen lauluvihot, joissa estottomasti lainattiin, yhdisteltiin ja runoiltiin uudelleen niin Eino Leinoa kuin arkkiveisujakin. Henriksson on jäljittänyt muistokirjoista tunnettujen runoilijoiden tuotantoa, joista on luettelo liitteessä. Luettelo jää tässä tutkimuksessa varsin irralliseksi, ja se olisi paremminkin jatkotutkimuksen aihe.

\section{YSTÄVYYSKULTTI JA KUKKASYMBOLIIKKA}

Millainen sitten on muistokirjoissa rakennettu hyvän naisen malli? Muutokset ovat hätkähdyttävän hitaita mutta havaittavia: 1800-luvulla naisen ideaaliin kuuluivat viattomuus ja sulokkuus (ruots. behag), mutta 1900-luvun aineistossa painottuivat iloisuus ja ahkeruus tyttöjen ihanneominaisuuksina. Koti on muistokirjojen keskeisiä ja pysyviä teemoja, sekä nostalgisoitu lapsuudenkoti että tytön tuleva aviollinen satama.

Ystävyys on kuitenkin muistokirjoissa vielä vahvempi teema kuin rakkaus, mikä liittyy osaltaan niiden kirjoittajien iän nuorentumiseen. Ystävyyskultti, romanttissävyinen ystävyys samaa sukupuolta olevien naisten välillä toistuu 1800-luvun muistokirjojen runoissa, joissa pohditaan ikuista ystävyyttä eri näkökulmista. Henriksson havainnoi oivaltavasti myös tämän ystävyyskultin emotionaalisia jännitteitä - runojen ylikorostettu vaatimattomuus on usein peiteltyä huomion vaatimista (s. 166).

Henriksson erittelee myös muistokirjojen yllättävän samanlaisena pysyvää kuvakieltä, kukkasymboliikkaa sekä polkua ja merta elämän metaforina. Kuvakielen yhtenäisyys on yllättävän vahvaa, ja sen rikkovat vain joidenkin uusimpien esimerkkien parodiset nonsense-runot. Minkäänlaisesta feministisestä muistokirjatradition uudistamisesta (uudelleen kirjoitettujen kansansatujen tapaan) ei aineistossa ole merkkejä.

\section{SUKUPUOLI KÄSITELTY - MISSÄ ON LUOKKA?}

Muistokirjoista tuli 1800-luvun lopulla kaikkien yhteiskuntaluokkien, myös maaseudun nuorten naisten ja työläistyttöjen traditiota (s. 55). Muistokirjatradition yhteys yhteiskuntaluokkaan jää kuitenkin tutkimuksessa ohueksi. Omien havaintojeni mukaan muistokirjojen kukkasymboliikka toistui myös 1900-luvun alun työläistyttöjen lauluvihoissa ja käsinkirjoitettujen lehtien runoissa, vaikka se sai niissä uudenlaisia ideologisia sisältöjä. Omassa lapsuudessani tärkeitä muistokirjatradition välittäjiä olivat kotiapulaiset, pohjoiskarjalaiset tytöt, joita ehti vierailla perheessämme melko monia ennen kouluikääni. Muistelen jopa, että sain ensimmäisen muistokirjani eräältä kotiapulaiselta. 


\section{TYTTÖKULTTUURIN PITKÄT KAARET}

Yhteiskunnallisen tarkastelun ohuus liittyy tutkimusasetelman metodologiseen ongelmaan. Aineisto on hyvin laaja ja heterogeeninen, tekijä tiivistää tuloksensa kiitettävästi, mutta samalla paljon aineiston vivahteita ja kontekstitietoja hämärtyy. Lähes kahdensadan vuoden aikana tuotettuja runoja tarkastellaan yhtenäisenä aineistomassana, ja esimerkkien aikamäärittelytkin ovat välillä varsin epämääräisiä. Esimerkiksi muistokirjojen uudenlaiset merkitykset 1900-luvun loppupuolen lastenkulttuurina jäävät vähemmälle tarkastelulle ehkä siksi, että niistä on olemassa vähemmän taustatutkimusta kuin 1800-luvun ja 1900-luvun alun naisten kasvatuksesta. Osittain avoimeksi jää, mistä muistokirjoissa rakennettu hyvä naisen malli loppujen lopuksi kertoo. Kertooko se nuorten naisten omista käsityksistä vai niistä arvoista, joita vanhemmat haluavat siirtää lapsille? Missä määrin 1900-luvun tai sotienjälkeisen ajan muistovihot ovat lastenkulttuuria, missä määrin kasvatuksen välineitä? Parodiset elementit vahvistuvat myös 1900-luvun loppupuolella, mutta näihin puututaan vain lyhyesti.

Laajojen tradition kaarien hahmottaminen on folkloristisen tutkimuksen ominta annettavaa historiantutkimukselle ja muille lähitieteille. Johtaako tämä traditiotietoisuus kuitenkin siihen, että yhteiskunnalliset erot ja poliittiset tapahtumat taustavaikuttajina hämärtyvät? Tradition kaarien ja poliittis-yhteiskunnallisen kontekstin yhdistäminen on folkloristisen tutkimuksen suurimpia haasteita. Tyttökulttuurin historian tutkimukseen (Eva Lis Bjurman, Jessica Parland-von Essen) Blanka Henrikssonin tutkimus tuo merkittävän folkloristisen lisän. Toivottavasti suomalaisen, suomenruotsalaisen ja ruotsalaisen tutkimuksen välille voidaan rakentaa nykyistä vahvempia yhteyksiä ja löytää hedelmällisiä vertailuasetelmia.

Lukiessani Henrikssonin tutkimusta alkoi moni asia tuntua merkillisen tutulta ja tämänpäiväiseltä, kuten ystäväpiirin laskeminen, kukkaiskieli ja pienet muistoesineet, joita on liitetty muistokirjoihin. Mitä muuta Facebook on ellei tämän päivän aikuisten muistokirja? Monet lastenkulttuuriksi marginaalistuneet käsikirjoituskulttuurin muodot ovat heränneet uudestaan eloon digitaalisessa mediassa ja niistä on tullut osa aikuisten (jopa keski-ikäisten) jokapäiväistä kanssakäymistä, jossa leikittely, seurustelu ja kansalaistoiminta limittyvät. Näiden uusien ilmiöiden tutkimukselle folkloristeilla voi olla paljon annettavaa.

\section{KirJallisuUs}

GRUBER GARVEY, ELLEN 2007: Imitation is the Sincerest from of Appropriation. - Common-place 7(3) [online]. <http://www.common-place.org/vol-07/no-03/ garvey> [4.10.2008.]

\section{Kirsti Salmi-Niklander on Helsingin yliopiston folkloristiikan dosentti.}

